\title{
ONREL
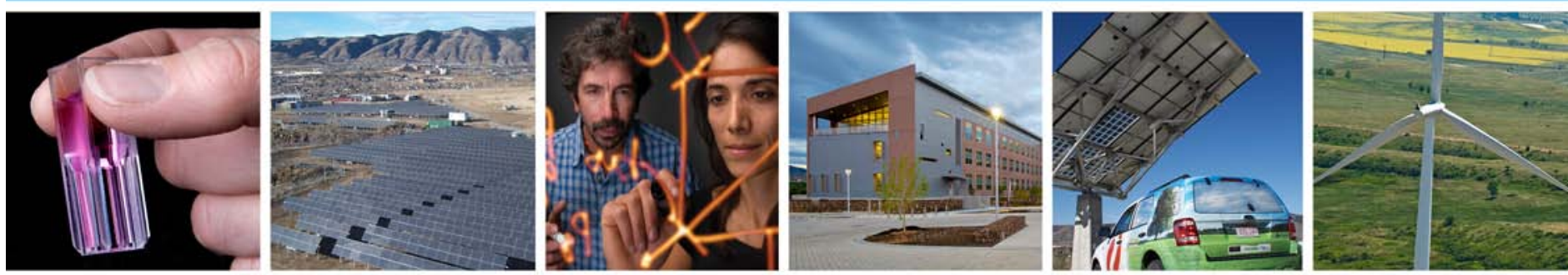

\section{Sodium-Doped Molybdenum Targets for Controllable Sodium Incorporation in CIGS Solar Cells}

\section{Preprint}

Lorelle M. Mansfield, Ingrid L. Repins, Stephen Glynn, Joel W. Pankow, Matthew R. Young, Clay DeHart, Rajalakshmi Sundaramoorthy, Carolyn L. Beall, and Bobby To National Renewable Energy Laboratory

Michael D. Carducci and David M. Honecker Climax Molybdenum Technology Center

Presented at the $37^{\text {th }}$ IEEE Photovoltaic Specialists Conference (PVSC 37)

Seattle, Washington

June 19-24, 2011

NREL is a national laboratory of the U.S. Department of Energy, Office of Energy Efficiency \& Renewable Energy, operated by the Alliance for Sustainable Energy, LLC.

Conference Paper

NREL/CP-5200-50722

July 2011

Contract No. DE-AC36-08G028308 


\section{NOTICE}

The submitted manuscript has been offered by an employee of the Alliance for Sustainable Energy, LLC (Alliance), a contractor of the US Government under Contract No. DE-AC36-08GO28308. Accordingly, the US Government and Alliance retain a nonexclusive royalty-free license to publish or reproduce the published form of this contribution, or allow others to do so, for US Government purposes.

This report was prepared as an account of work sponsored by an agency of the United States government. Neither the United States government nor any agency thereof, nor any of their employees, makes any warranty, express or implied, or assumes any legal liability or responsibility for the accuracy, completeness, or usefulness of any information, apparatus, product, or process disclosed, or represents that its use would not infringe privately owned rights. Reference herein to any specific commercial product, process, or service by trade name, trademark, manufacturer, or otherwise does not necessarily constitute or imply its endorsement, recommendation, or favoring by the United States government or any agency thereof. The views and opinions of authors expressed herein do not necessarily state or reflect those of the United States government or any agency thereof.

Available electronically at http://www.osti.gov/bridge

Available for a processing fee to U.S. Department of Energy and its contractors, in paper, from:

U.S. Department of Energy

Office of Scientific and Technical Information

P.O. Box 62

Oak Ridge, TN 37831-0062

phone: 865.576.8401

fax: 865.576 .5728

email: mailto:reports@adonis.osti.gov

Available for sale to the public, in paper, from:

U.S. Department of Commerce

National Technical Information Service

5285 Port Royal Road

Springfield, VA 22161

phone: 800.553 .6847

fax: 703.605.6900

email: orders@ntis.fedworld.gov

online ordering: http://www.ntis.gov/help/ordermethods.aspx

Cover Photos: (left to right) PIX 16416, PIX 17423, PIX 16560, PIX 17613, PIX 17436, PIX 17721

Printed on paper containing at least $50 \%$ wastepaper, including $10 \%$ post consumer waste. 


\title{
SODIUM-DOPED MOLYBDENUM TARGETS FOR CONTROLLABLE SODIUM INCORPORATION IN CIGS SOLAR CELLS
}

\author{
Lorelle M. Mansfield ${ }^{1}$, Ingrid L. Repins ${ }^{1}$, Stephen Glynn ${ }^{1}$, Michael D. Carducci ${ }^{2}$, David M. Honecker ${ }^{2}$, Joel W. Pankow $^{1}$, \\ Matthew R. Young ${ }^{1}$, Clay DeHart ${ }^{1}$, Rajalakshmi Sundaramoorthy ${ }^{1}$, Carolyn L. Beall ${ }^{1}$, and Bobby To ${ }^{1}$ \\ ${ }^{N}$ National Renewable Energy Laboratory, Golden, Colorado, USA \\ ${ }^{2}$ Climax Molybdenum Technology Center, Sahuarita, Arizona, USA
}

\begin{abstract}
The efficiency of $\mathrm{Cu}(\mathrm{In}, \mathrm{Ga}) \mathrm{Se}_{2}$ (CIGS) solar cells is enhanced when $\mathrm{Na}$ is incorporated in the CIGS absorber layer. This work examines $\mathrm{Na}$ incorporation in CIGS utilizing Na-doped Mo sputtered from targets made with sodium molybdate-doped (MONA) powder. Mo:Na films with varying thicknesses were sputtered onto Mo-coated borosilicate glass (BSG) or stainless steel substrates for CIGS solar cells. By use of this technique, the Na content of CIGS can be varied from near-zero to higher than that obtained from a soda-lime glass (SLG) substrate. Targets and deposition conditions are described. The doped Mo films are analyzed, and the resulting devices are compared to devices fabricated on Mo-coated SLG as well as Mo-coated BSG with NaF. Completed devices utilizing MONA exceeded $15.7 \%$ efficiency without anti-reflective coating, which was consistently higher than devices prepared with the NaF precursor. Strategies for minimizing adhesion difficulties are presented.
\end{abstract}

\section{INTRODUCTION}

Laboratory-scale $\mathrm{Cu}(\mathrm{In}, \mathrm{Ga}) \mathrm{Se}_{2}$ (CIGS) solar cells have now reached over $20 \%$ conversion efficiency [1]. Na plays a crucial role in the fabrication of the world-record devices. Therefore, high-efficiency CIGS solar cells are typically deposited on soda-lime glass [2]. At the high growth temperatures $\left(\sim 600^{\circ} \mathrm{C}\right)$, Na from the glass diffuses through the molybdenum back contact and into the forming CIGS film. This makes the solar cell efficiency very dependent on the properties of the molybdenum back contact $[3,4]$. The advent of high-volume CIGS manufacturing necessitates $\mathrm{Na}$ incorporation methods that are precise, manufacturable, and controllable over a wide range of $\mathrm{Na}$ concentrations. A reliable $\mathrm{Na}$ delivery system will increase the reproducibility of CIGS device performance. Additionally, another source of $\mathrm{Na}$ is required in order to fabricate solar cells on Na-free substrates such as stainless steel or polymer film. One proven $\mathrm{Na}$ precursor is $\mathrm{NaF}$ [5-8]. However, CIGS films deposited on NaF can display adhesion problems, particularly when some portion of the $\mathrm{NaF}$ precursor is not consumed during CIGS growth, such as at lower deposition temperatures or large $\mathrm{NaF}$ thicknesses. The adhesion issues limit the amount of $\mathrm{Na}$ supplied from $\mathrm{NaF}$ to lower than that supplied by sodalime glass. Climax Molybdenum Technology Center has developed sodium-containing molybdenum (MONA) that eliminates the need to extract $\mathrm{Na}$ from glass. We have produced solar cells with $16.6 \%$ efficiency (total-area, with anti-reflective coating) using these Na-doped molybdenum targets.

\section{EXPERIMENTAL}

Sputtering target fabrication involves several steps. First, MONA powder was produced by mixing sodium molybdate $(\sim 15 \%)$ and molybdenum powder $(\sim 85 \%)$ in deionized water and spray-drying the resulting slurry. The powder used in this fabrication contained approximately $3 \%[w t]$ sodium (9.6\%[at]), as measured by ICP-OES. The powder was consolidated into a suitable form to fabricate sputtering targets using cold isostatic pressing followed by an encapsulated hot isostatic pressing process. Targets with the stated composition and fabricated using this proces, densify to a range of $94.8 \%$ to $98.4 \%$ (theoretical maximum density $8.23 \mathrm{~g} / \mathrm{cc}$ ) depending on the conditions used.

CIGS solar cells were fabricated with three different sodium sources including $\mathrm{NaF}, \mathrm{Mo}: \mathrm{Na}$, and soda-lime glass (SLG). Sodium-free borosilicate glass (BSG) with the addition of a $500 \AA$ chromium barrier-layer was used as the substrate for the NaF samples to ensure that no additional source of $\mathrm{Na}$ existed. The back contact for the $\mathrm{NaF}$ samples included an approximately $8000 \AA$ molybdenum layer, and $\mathrm{NaF}$ was deposited on top in an ebeam evaporation system. This configuration is shown in Fig. 1a and Fig. 1b. Mo:Na samples were prepared on chromium-coated BSG (see Fig. 1d and 1e) or chromiumcoated stainless steel (SS) (see Fig. 1f) with $\sim 8000 \AA$ Mo and Mo: $\mathrm{Na}$ on top. Mo: Na was DC-sputtered to the desired thickness, ranging from $20 \mathrm{~nm}$ to $1000 \mathrm{~nm}$, with a chamber pressure of 10 mtorr. In some cases a $\sim 500 \AA$ Mo cap layer was added to promote CIGS adhesion. This configuration is shown in Fig. 1e and Fig. 1f and is known as a "Mo:Na sandwich." Comparison samples were also prepared on the laboratory-standard SLG with a Mo back contact between $5000 \AA$ and $10000 \AA$ thick (see Fig. 1c). In general, CIGS depositions contained a 1 in. by 3 in. piece of substrate with Mo:Na (see Fig. 1d, 1e, or 1f), with $\mathrm{NaF}$ (see Fig. 1a or 1b), and standard Mo on SLG (see Fig. 1c). The CIGS absorber layer was deposited via NREL's three-stage process with temperatures reaching approximately $60^{\circ} \mathbb{C}$ [9-13], as measured with a thermocouple placed on the backside of the glass. Devices were finished with standard processing described elsewhere [11, 12, 14], including $\mathrm{CdS}$, bi-layer $\mathrm{ZnO}$, and $\mathrm{Ni} / \mathrm{Al}$ grids. An anti-reflective (AR) coating, $1000 \AA$ of $\mathrm{MgF}_{2}$, was applied to only two selected samples. Quoted 
efficiencies in this paper are without AR coating, except where specifically designated otherwise.

(a)

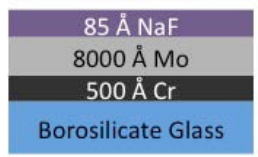

$85 \mathrm{~A} \mathrm{NaF}$

(d)

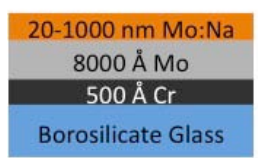

$\mathrm{Mo}: \mathrm{Na}$ (b)

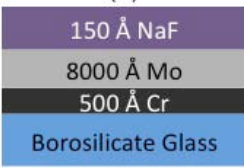

$150 \AA \mathrm{AaF}$

(e)

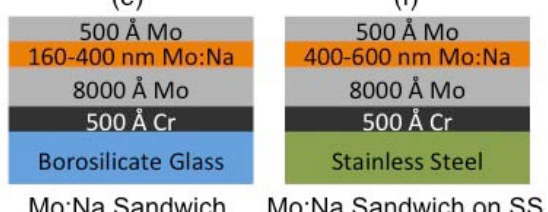

Mo:Na Sandwich Mo:Na Sandwich on SS

(c)

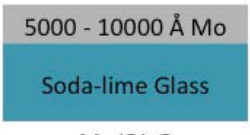

$\mathrm{Mo} / \mathrm{SLG}$

(f) $600 \mathrm{~nm} M 0: N$ $8000 \AA \AA \mathrm{Mo}$ $500 \AA \mathrm{Cr}$ Mo:Nandwich on SS

Figure 1 Substrate and back contact configurations.
The layers are not drawn to scale. The layers are not drawn to scale.

\section{RESULTS AND DISCUSSION}

\section{Sodium Content}

Sodium content in the CIGS absorber layer as a function of Mo: Na thickness was investigated using secondary ion mass spectroscopy (SIMS). Fig. 2 shows an average of the positive $\mathrm{Na}$ counts within the bulk of the CIGS film vs. the Mo:Na thickness. (Here, the "bulk" of the film is defined by excluding $0.5 \mathrm{um}$ from the top of the film and $0.5 \mathrm{um}$ at the CIGS/Mo interface.) For comparison, horizontal lines on the graph represent $\mathrm{Na}$ counts from a high-efficiency CIGS film on SLG (dashed black line), from a CIGS film deposited on $150 \AA$ of $\mathrm{NaF}$ (dashed pink line), and from $\mathrm{CIGS}$ on $85 \AA$ of $\mathrm{NaF}$ (dashed purple line). CIGS samples grown directly on Mo:Na films (see Fig. 1d) are indicated with blue diamonds in Fig. 2. A blue line guides the eye to show that by using $1000 \mathrm{~nm}$ of $\mathrm{Mo:Na}$, the $\mathrm{Na}$ content is more than double the $\mathrm{Na}$ content measured in high-efficiency CIGS on SLG. At the high Mo:Na thicknesses, however, adhesion issues inhibited device performance and will be discussed later. Note that the 500 A Mo cap (see Fig. 1e) slightly decreases the amount of $\mathrm{Na}$ in the CIGS for a given Mo:Na thickness as indicated by the red circles in Fig. 2. The level of $\mathrm{Na}$ in the CIGS of Mo:Na samples surpasses that of $85 \AA \mathrm{NaF}$ in all but the thinnest $(20 \mathrm{~nm}) \mathrm{Mo}: \mathrm{Na}$ layer. $\mathrm{Na}$ content in CIGS is higher than that obtained with $150 \AA \mathrm{NaF}$ in Mo:Na thicknesses over $200 \mathrm{~nm}$.

\section{Device Performance}

To determine the efficiency of each solar cell device, current density-voltage $(\mathrm{J}-\mathrm{V})$ measurements were performed under one-sun conditions. Fig. 3 includes example J-V curves for illuminated solar cells with $\mathrm{NaF}$ (green dotted line), Mo:Na (pink line), and SLG (purple dashed line) as the Na source. The device parameters are shown in Table 1. At lower Mo:Na thicknesses, the opencircuit voltages $\left(\mathrm{V}_{\mathrm{oc}}\right)$ were not as high as the $\mathrm{V}_{\mathrm{oc}}$ of devices fabricated on SLG. However, fill factor (FF), $V_{o c}$, and efficiency values were higher than those of the devices that had $\mathrm{NaF}$ as their $\mathrm{Na}$ source. The best device efficiency on Mo: $\mathrm{Na}, 16.6 \%$, was obtained on a $160-\mathrm{nm}$ Mo:Na sandwich with AR coating. The other parameters of note for this champion device (from a different CIGS deposition that is not shown on the graph) are $\mathrm{V}_{\mathrm{oc}}=0.634$ $\mathrm{V}, \mathrm{J}_{\mathrm{sc}}=-35.3 \mathrm{~mA} / \mathrm{cm}^{2}$, and $\mathrm{FF}=74.2 \%$.

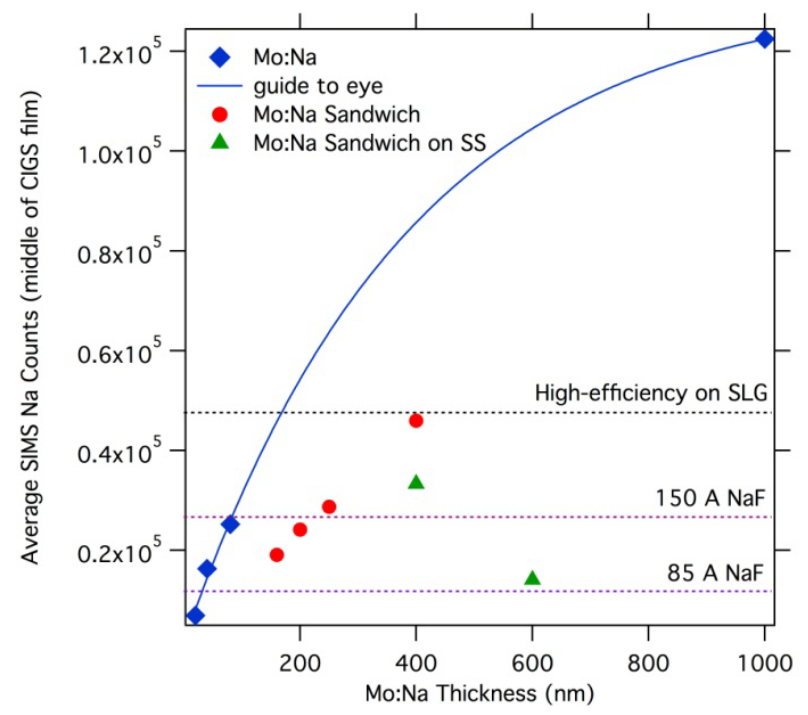

Figure 2 Average SIMS Na counts in CIGS films versus Mo:Na thickness. Horizontal lines represent the average SIMS Na counts in a high-efficiency CIGS film (black), CIGS grown on $150 \AA \mathrm{NaF}$ (pink), and $85 \AA$ NaF (purple).

The efficiencies of devices fabricated on Mo:Na were compared to those on SLG. Since the individual CIGS depositions on SLG varied in efficiency from $13.3 \%$ to $17.9 \%$, we calculated for each $\mathrm{Mo}: \mathrm{Na}$ piece the percentage of the SLG companion piece efficiency that it achieved. The most efficient Mo: Na device for each CIGS deposition was divided by the most efficient device on SLG for that same deposition, and then multiplied by 100 to obtain the percentage on the $y$-axis in Fig. 4. As Mo: Na thickness increased, so did the performance of the devices. This finding is consistent with observations in the SIMS data in Fig. 2. The trend is displayed in Fig. 4, along with a green shaded area representing the range of compared efficiencies (to devices on SLG) for devices on $85 \AA \mathrm{NaF}$, and a blue shaded area for devices on $150 \AA$ $\mathrm{NaF}$. 


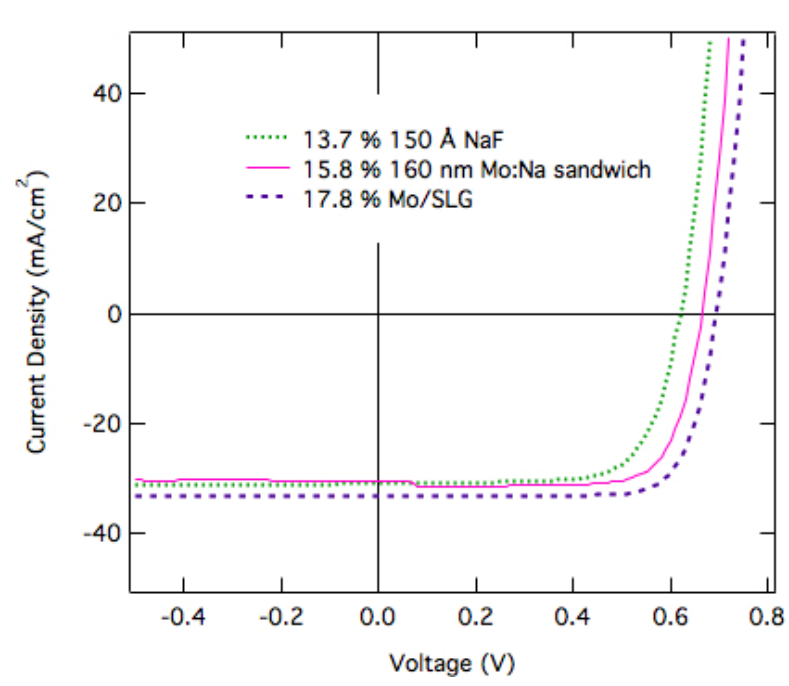

Figure 3 Current-density vs. voltage curves of sample devices under one-sun illumination. Included are a cell fabricated on a NaF-coated substrate (green dotted line), on Mo:Na (pink line), and on SLG (purple dashed line). Notice that the Mo: Na sample has a higher open-circuit voltage than the NaF sample.

Table 1 Parameters for devices shown in Fig. 3. Fill factor (FF), open-circuit voltage $\left(V_{o c}\right)$, and efficiency (Eff) are higher for devices on Mo: $\mathrm{Na}$ than devices on $\mathrm{NaF}$. Short-circuit current $\left(\mathrm{J}_{\mathrm{sc}}\right)$ is comparable for $\mathrm{NaF}$ and Mo:Na devices, but higher for devices on SLG.

\begin{tabular}{|c|c|c|c|c|}
\hline Substrate & $\begin{array}{c}\mathbf{V}_{\text {oc }} \\
(\mathbf{V )}\end{array}$ & $\begin{array}{c}\mathbf{J}_{\text {sc }} \mathbf{2} \\
\left(-\mathbf{m A} / \mathbf{c m}^{\mathbf{~}}\right.\end{array}$ & $\begin{array}{c}\text { FF } \\
\mathbf{( \% )}\end{array}$ & $\begin{array}{c}\text { Eff } \\
\mathbf{( \% )}\end{array}$ \\
\hline $150 \AA \mathrm{NaF}$ & 0.620 & 30.9 & 71.3 & 13.7 \\
\hline $160 \mathrm{~nm} \mathrm{Mo:Na}$ & 0.664 & 30.6 & 77.5 & 15.8 \\
\hline $\mathrm{Mo} / \mathrm{SLG}$ & 0.694 & 33.1 & 77.4 & 17.8 \\
\hline
\end{tabular}

The efficiencies of devices fabricated on Mo: Na were also compared to those in the same deposition on NaF. The yaxis in Fig. 5 is the best Mo:Na device efficiency divided by the best $\mathrm{NaF}$ device efficiency from the same CIGS deposition, multiplied by 100 . Most of the points in the graph fall above the dotted line at $100 \%$, indicating that for the individual CIGS depositions, devices on thicker Mo:Na consistently reach or exceed the devices on $150 \AA \mathrm{NaF}$.

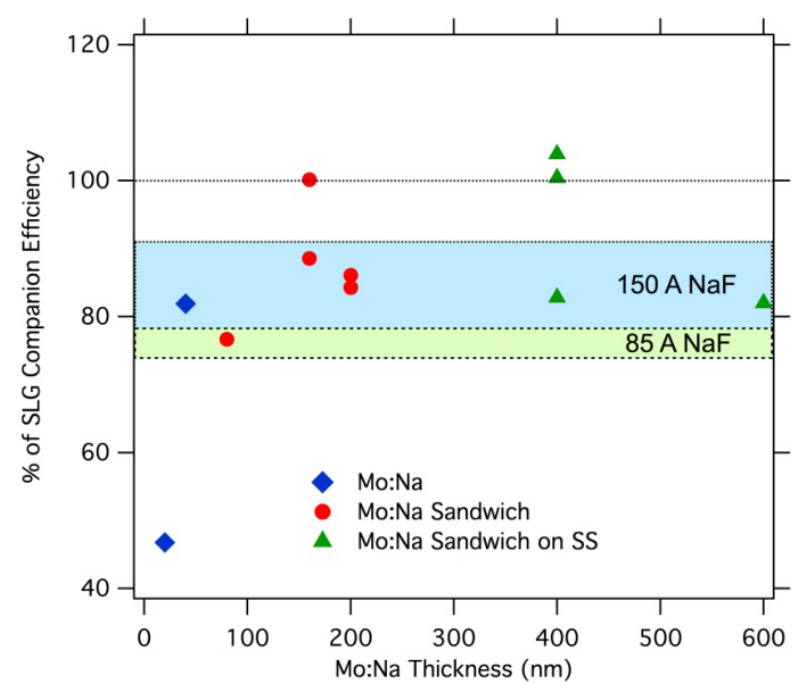

Figure 4 Percentage of SLG companion efficiency versus Mo:Na thickness. The $\mathrm{y}$-axis is the best Mo: Na device efficiency divided by the best SLG device efficiency from the same CIGS deposition, multiplied by 100 . The light blue shaded area represents the range of efficiency comparison for devices fabricated on $150 \AA \mathrm{NaF}$. The light green shaded area shows the same for devices fabricated on $85 \AA \mathrm{NaF}$.

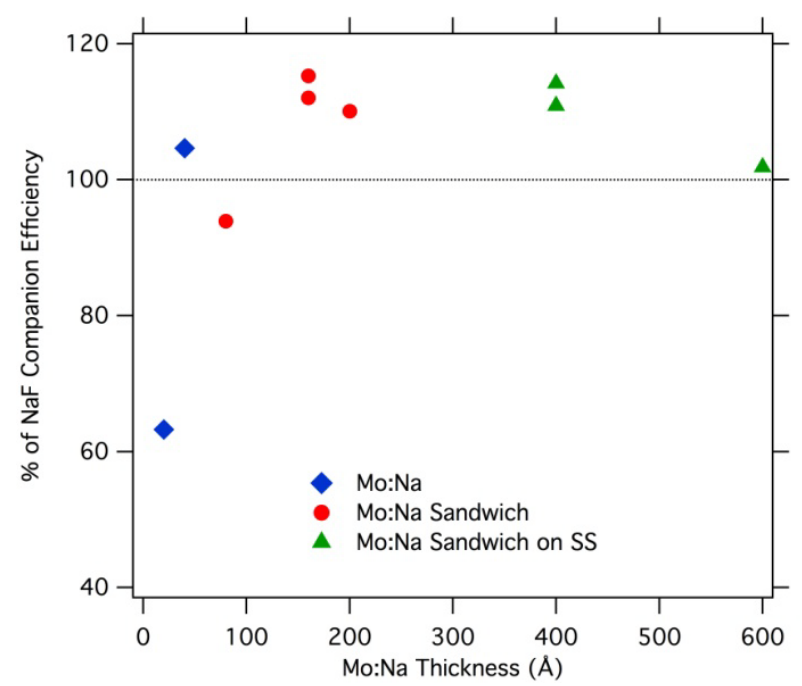

Figure 5 Percentage of $\mathrm{NaF}$ companion efficiency versus Mo:Na thickness. The $\mathrm{y}$-axis is the best Mo:Na device efficiency divided by the best $\mathrm{NaF}$ device efficiency from the same CIGS deposition, multiplied by 100 . Samples with higher Mo:Na thicknesses easily reach or exceed the efficiency of devices on $150 \AA$ NaF.

\section{Adhesion Issues}

Device results for the thickest $\mathrm{Mo:Na}$ films are not reported because producing a fully adherent CIGS layer on these substrates was challenging. CIGS deposited directly on Mo: $\mathrm{Na}$ (substrate depicted in Fig. 1d) was 
prone to peeling (see right side of Fig. 5 inset) unless a three-minute pre-deposition selenization was performed at $\sim 400^{\circ} \mathrm{C}$. For $\mathrm{Mo}: \mathrm{Na}$ thicknesses above $100 \mathrm{~nm}$, selenization did not mitigate the adhesion issue. Energydispersive $x$-ray spectroscopy (EDX) performed on the backside of peeled CIGS flakes (see Fig. 5) did not reveal Mo, indicating that the films delaminated at the CIGS/Mo:Na interface.

The CIGS adhesion was enhanced for Mo: Na thicknesses up through $200 \mathrm{~nm}$ by adding a thin layer of Mo on top of the Mo: Na as shown in Fig. 1e. However, for $400 \mathrm{~nm}$ Mo:Na on BSG with a Mo cap layer, scanning electron microscopy (SEM) (see Fig. 7a) revealed nodules on the substrate surface. By performing Auger electron spectroscopy (AES) on the nodules (see Fig. 7b), we detected much more $\mathrm{Na}$ and $\mathrm{O}$ than off the nodules (see Fig. 7c). It is likely that the nodules cause poor adhesion due to too much $\mathrm{Na}$ at the surface, similar to what is observed when using thick NaF precursor layers. We understand within bounds (up to $400 \mathrm{~nm} \mathrm{Mo:Na,} \mathrm{just}$ below the amount of $\mathrm{Na}$ obtained using SLG) how to achieve adherent device stacks. However, we have not used the thickest Mo: Na films in high-performing devices because of adhesion and related difficulties.

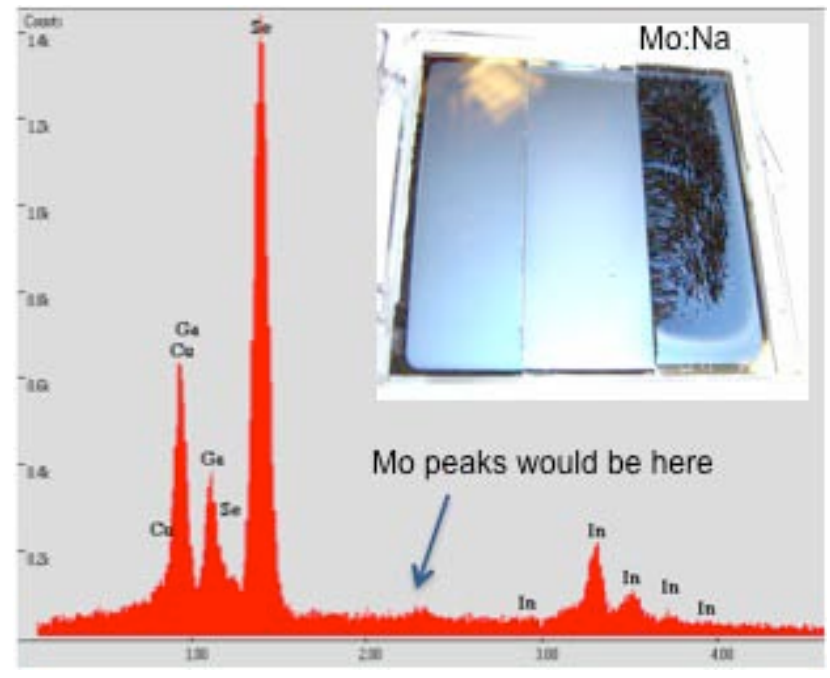

Figure 6 The EDX graph does not show Mo on the back of the CIGS flakes, indicating that the peeling occurred at the CIGS/Mo:Na interface. Inset is a photograph of the CIGS film on all three substrates. The peeling film on the right is CIGS deposited directly on Mo:Na, as in Fig. 1d.
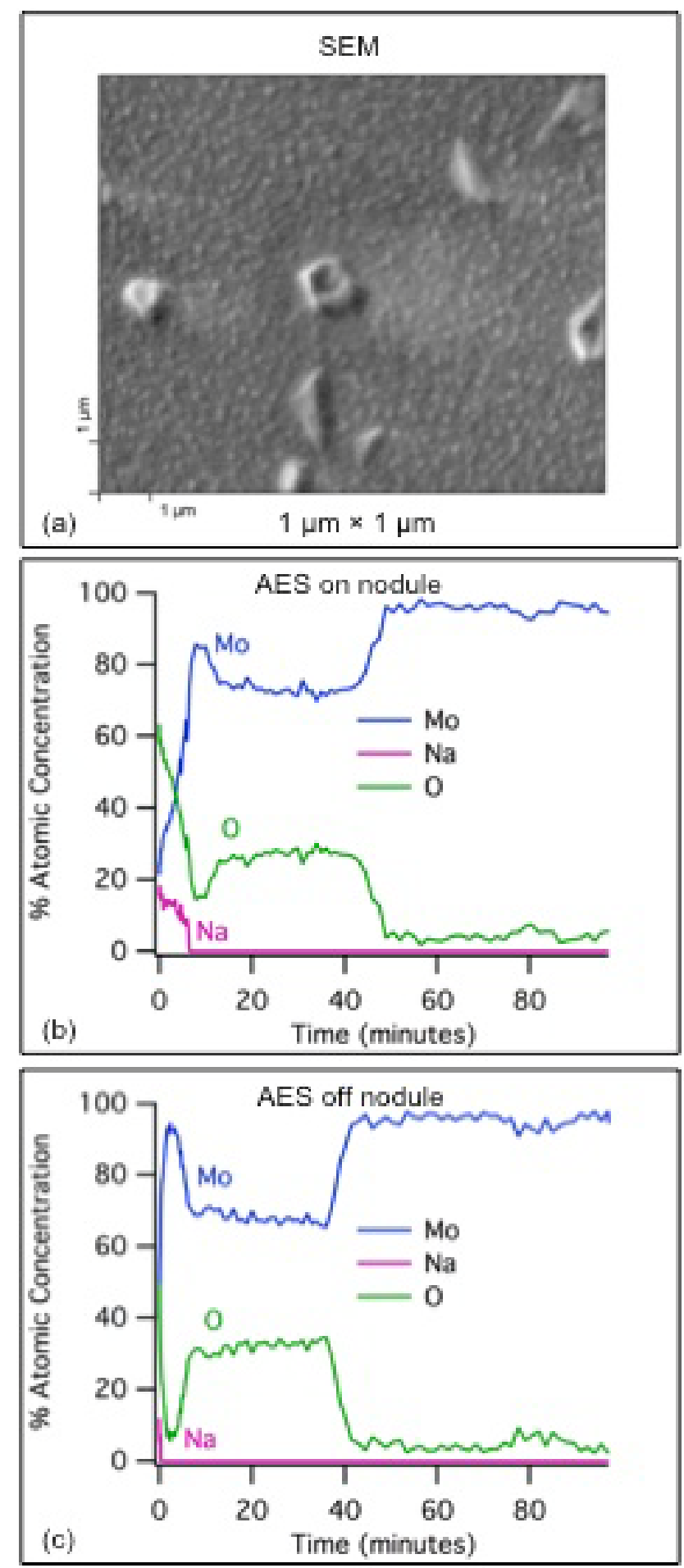

Figure 7 SEM of nodules on the surface of $400-\mathrm{nm}$ Mo:Na sandwich (a). AES on (b) and off (c) one of the nodules shows that $\mathrm{Na}$ is aggregating and oxidizing on the surface. 
To further promote CIGS adhesion, Mo:Na was deposited on stainless steel (SS) substrates (see Fig. 1f) with the reasoning that the rougher surface might inhibit the formation of the large $\mathrm{Na}$ nodules of Fig. 7a. In general, the CIGS did adhere better to the Mo: Na on SS. We were able to fabricate devices on Mo:Na thicknesses up to 600 $\mathrm{nm}$. However, average $\mathrm{Na}$ SIMS counts for the CIGS on SS substrates with Mo:Na were lower than those on Mo:Na on glass (see green triangles in Fig. 2.) This may be due in part to the difficulty in obtaining SIMS depth resolution for these rougher samples, or it may be a real physical effect. The devices on SS were less efficient than those on Mo: $\mathrm{Na}$ and glass, which is expected, because SS is a rougher substrate and the steel may contribute some harmful impurities to the CIGS [15]. While initial efficiency results from Mo: Na on SS were very promising (see the green triangles above $100 \%$ in Fig. 4), the SLG efficiency in these CIGS depositions was lower than normal $(\sim 13 \%)$. Subsequent CIGS depositions yielded better results on SLG substrates, but the efficiencies on SS remained lower. J-V measurements for the best CIGS cell on Mo:Na/SS and its SLG and $\mathrm{NaF}$ companion devices are shown in Fig. 8. The device parameters are shown in Table 2. As for the case of BSG, CIGS solar cells on SS with Mo:Na performed better than those with $\mathrm{NaF}$ as the sodium source.

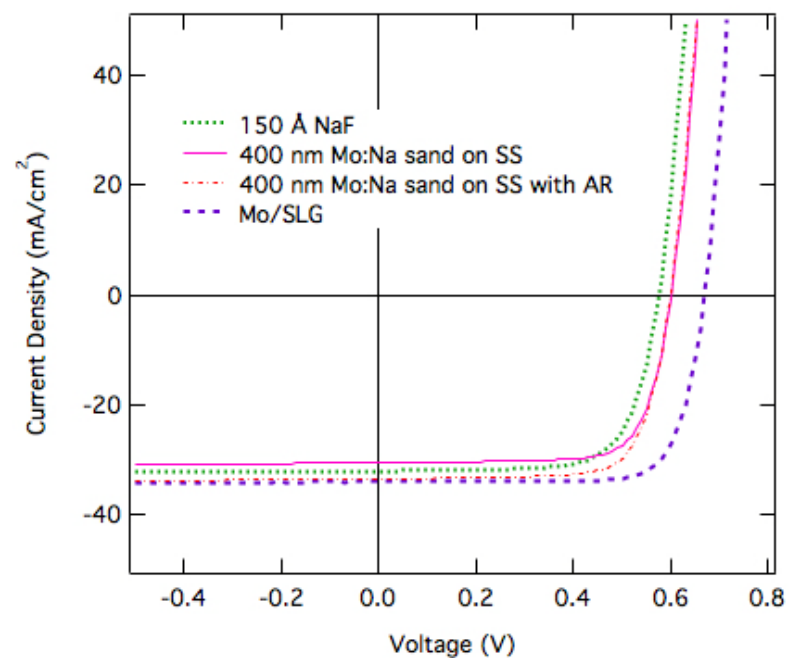

Figure 8 Current-density vs. voltage curves of sample devices under one-sun illumination. Included are a cell fabricated on a NaF-coated substrate (green dotted line), on Mo:Na on SS (pink line), and on SLG (purple dashed line). An AR coating was applied to the Mo:Na on SS device (red dash and dotted line).
Table 2 Parameters for devices shown in Fig. 8. Fill factor (FF), open-circuit voltage $\left(V_{o c}\right)$, and efficiency (Eff) are higher for devices on Mo: Na than devices on $\mathrm{NaF}$. Short-circuit current $\left(\mathrm{J}_{\mathrm{sc}}\right)$ is comparable for $\mathrm{NaF}$ and Mo:Na devices, but higher for devices on SLG.

\begin{tabular}{|c|c|c|c|c|}
\hline Substrate & $\begin{array}{c}\mathbf{V}_{\text {oc }} \\
(\mathbf{V})\end{array}$ & $\begin{array}{c}\mathbf{J}_{\text {sc }} \mathbf{2} \\
(\mathbf{- m A / c m})\end{array}$ & $\begin{array}{c}\text { FF } \\
\mathbf{( \% )}\end{array}$ & $\begin{array}{c}\text { Eff } \\
\mathbf{( \% )}\end{array}$ \\
\hline $150 \AA \mathrm{NaF}$ & 0.576 & 32.0 & 71.3 & 13.2 \\
\hline $\begin{array}{c}\text { 400 nm Mo:Na } \\
\text { on SS }\end{array}$ & 0.601 & 30.5 & 74.6 & 13.7 \\
\hline $\begin{array}{c}400 \mathrm{~nm} \mathrm{Mo:Na} \\
\text { on SS with AR }\end{array}$ & 0.601 & 33.3 & 74.3 & 14.9 \\
\hline Mo/SLG & 0.671 & 34.0 & 77.3 & 17.6 \\
\hline
\end{tabular}

CONCLUSION

High-efficiency CIGS solar cells were fabricated using Nadoped Mo targets. Devices produced on the Mo:Na had higher $\mathrm{V}_{\mathrm{oc}}, \mathrm{FF}$, and efficiency than those on NaF. Our best device with $16.6 \%$ efficiency was fabricated on $160 \mathrm{~nm}$ of Mo: $\mathrm{Na}$ with a $500-\AA$ Mo cap layer and an anti-reflective coating. SIMS revealed that CIGS grown on $400 \mathrm{~nm}$ $\mathrm{Mo}: \mathrm{Na}$ had higher $\mathrm{Na}$ incorporation than $\mathrm{CIGS}$ grown on NaF-coated substrates. SIMS data from the thickest Mo: $\mathrm{Na}$ layers show that $\mathrm{Na}$ content in the CIGS can be made to exceed that in high-efficiency devices on SLG. However, additional effort is needed to obtain acceptable adhesion for these thicker Mo:Na layers. Based on these data, Mo:Na may provide a manufacturing option for controllable $\mathrm{Na}$ incorporation in CIGS solar cells.

\section{ACKNOWLEDGEMENTS}

Thanks to Miguel Contreras and Rommel Noufi for valuable CIGS discussions, and Miguel for suggesting SS substrates. The Climax Technology Center acknowledges Chris Michaluk for his initiation of and contributions to this project. This work was supported by the U.S. Department of Energy under Contract No. DE-AC36-08-G028308 with the National Renewable Energy Laboratory.

\section{REFERENCES}

[1] P. Jackson et al., "New world record efficiency for $\mathrm{Cu}(\mathrm{In}, \mathrm{Ga}) \mathrm{Se} 2$ thin-film solar cells beyond 20\%," Prog Photovoltaics Res Appl, 2011, pp. online.

[2] I. Repins et al., "19.9\%-efficient $\mathrm{ZnO} / \mathrm{CdS} / \mathrm{CulnGaSe} 2$ solar cell with $81.2 \%$ fill factor," Prog Photovoltaics, 16, 2008, pp. 235-239.

[3] H. A. Al-Thani et al., "The effect of Mo back contact on $\mathrm{Na}$ out-diffusion and device performance of $\mathrm{Mo} / \mathrm{Cu}(\mathrm{In}, \mathrm{Ga}) \mathrm{Se}-2 / \mathrm{CdS} / \mathrm{ZnO}$ solar cells," Twenty-Ninth IEEE PVSC, 2002, pp. 720-723.

[4] D. C. Fisher et al., "The effect of Mo morphology on the performance of $\mathrm{Cu}(\mathrm{In}, \mathrm{Ga}) \mathrm{Se} / \mathrm{sub} 2$ / thin films," Thirty-first IEEE PVSC, 2005, pp. 371-374. 
[5] M. A. Contreras et al., "On the role of $\mathrm{Na}$ and modifications to $\mathrm{Cu}(\mathrm{In}, \mathrm{Ga}) \mathrm{Se} 2$ absorber materials using thin-MF (M=Na, K, Cs) precursor layers [solar cells]," Twenty-Sixth IEEE PVSC, 1997, pp. 359-362.

[6] K. Granath, M. Bodegard, and L. Stolt, "The effect of $\mathrm{NaF}$ on $\mathrm{Cu}(\mathrm{In}, \mathrm{Ga}) \mathrm{Se}-2$ thin film solar cells," Sol. Energy Mater. Sol. Cells, 60, 2000, pp. 279-293.

[7] D. Rudmann et al., "Effects of NaF coevaporation on structural properties of $\mathrm{Cu}(\mathrm{In}, \mathrm{Ga}) \mathrm{Se}-2$ thin films," Thin Solid Films, 431, 2003, pp. 37-40.

[8] R. Caballero et al., "The effect of NaF precursors on low temperature growth of CIGS thin film solar cells on polyimide substrates," Phys. Status Solidi A, 206, 2009, pp. 1049-1053.

[9] U.S. Patent No. 5,436,204 (July 25, 1995).

[10] U.S. Patent No. 5,441,897 (August 15, 1995).

[11] M. A. Contreras et al., "Progress toward 20\% efficiency in $\mathrm{Cu}(\mathrm{In}, \mathrm{Ga}) \mathrm{Se} 2$ polycrystalline thin-film solar cells," Prog Photovoltaics Res Appl, 7, 1999, pp. 311-316.

[12] M. A. Contreras et al., "High efficiency $\mathrm{Cu}(\mathrm{In}, \mathrm{Ga}) \mathrm{Se}_{2}-$ based solar cells: processing of novel absorber structures," Twenty-Fourth IEEE PVSC, 1994, pp. 68-75.

[13] K. Ramanathan et al., "Properties of 19.2\% efficiency ZnO/CdS/CulnGaSe2 thin-film solar cells," Prog Photovoltaics, 11, 2003, pp. 225-230.

[14] M. A. Contreras et al., "Optimization of CBD CdS process in high-efficiency $\mathrm{Cu}(\mathrm{In}, \mathrm{Ga}) \mathrm{Se}$-2-based solar cells," Thin Solid Films, 403, 2002, pp. 204-211.

[15] P. Jackson et al., "Contamination of $\mathrm{Cu}(\mathrm{In}, \mathrm{Ga}) \mathrm{Se} 2$ Solar Cells by Metallic Substrate Elements," Ninteenth European PVSEC, 2004, p. 1936. 